\title{
Pengaruh Fraksi Air Buah Lemon (Citrus limon) terhadap Kadar Glukosa Darah Mencit Tua yang Diberi Pakan Tinggi Lemak
}

\author{
Rina Permatasari, ${ }^{1}$ Yuke Andriane, ${ }^{2}$ Herry Garna, ${ }^{3}$ \\ Oky Haribudiman, ${ }^{4}$ R.A. Retno Ekowati ${ }^{5}$ \\ ${ }^{1}$ Program Studi Pendidikan Dokter Universitas Islam Bandung, ${ }^{2}$ Departemen Farmakologi dan Terapi Fakultas \\ Kedokteran Universitas Islam Bandung, ${ }^{3}$ Bagian Ilmu Kesehatan Anak Fakultas Kedokteran Universitas Islam \\ Bandung, ${ }^{4}$ Bagian Obstetri dan Ginekologi Fakultas Kedokteran Universitas Islam Bandung, ${ }^{5}$ Bagian Biologi \\ Medik Fakultas Kedokteran Universitas Islam Bandung
}

\begin{abstract}
Abstrak
Diabetes melitus merupakan salah satu penyakit yang menjadi masalah terbesar pada abad 21. Obesitas (terutama obesitas viseral) dan resistensi insulin sering disertai dengan sekelompok kelainan yang disebut sindrom metabolik yang mencakup intoleransi glukosa, trigliserida tinggi, kolesterol HDL rendah, dan hipertensi. Lemon mengandung flavonoid yang dipercaya mempunyai aktivitas menurunkan kadar glukosa darah. Tujuan penelitian ini mengetahui perubahan kadar glukosa darah pada mencit tua yang diberi pakan tinggi lemak setelah pemberian fraksi air buah lemon (Citrus limon). Penelitian dilakukan di Laboratorium Hewan Gedung Farmasi ITB dan Laboratorium Hewan Fakultas Kedokteran Universitas Islam Bandung pada bulan April-Juni 2018. Metode penelitian ini adalah eksperimental laboratorium murni in vivo dengan desain penelitian rancangan acak lengkap terhadap 28 mencit tua jantan galur DDY yang terbagi dalam lima kelompok, yakni kontrol normal, kontrol negatif, konsentrasi 20,6 $\mathrm{mg} / 20 \mathrm{gBB}, 41,2 \mathrm{mg} / 20 \mathrm{gBB}$, dan 82,4 mg/20 gBB. Pengukuran glukosa darah puasa dilakukan setelah masa adaptasi, saat perlakuan (hari ke-15), dan setelah perlakuan menggunakan glukosameter. Analisis data menggunakan Uji Kruskall-Wallis dan Uji Friedman. Hasil penelitian menunjukkan perbedaan median GDP antarkelompok yang signifikan $(\mathrm{p}=0,05)$, perbedaan median GDP yang tidak signifikan $(\mathrm{p}=0,08)$, dan perbedaan median GDP yang tidak signifikan $(\mathrm{p}=0,66)$. Terdapat perbedaan median $\mathrm{GDP}_{1}-_{3}$ yang signifikan antara kelompok konsentrasi fraksi air buah lemon $(\mathrm{p}=0,04)$. Simpulan, fraksi air buah lemon memiliki efek menurunkan glukosa darah.
\end{abstract}

Kata kunci: Citrus limon, diabetes melitus, glukosa darah

\section{Effect of Water Fraction of Lemon (Citrus limon) on Blood Glucose Level of Old Mice Given High-fat Diet}

\begin{abstract}
Diabetes mellitus is one of the biggest problems of the $21^{\text {st }}$ century. Obesity (especially visceral obesity) and insulin resistance often present with a group of disorders commonly called metabolic syndrome including glucose intolerance, high triglycerides, low HDL cholesterol, and hypertension. Flavonoid compounds in lemon is believed to have blood glucose lowering activity. The purpose of this study was to determine changes in blood glucose level in old mice given a high-fat diet after administration of water fraction of lemon (Citrus limon). This study was held at Animal Laboratory of Pharmacy ITB and Animal Laboratory of Faculty of Medicine Bandung Islamic University in April to June 2018. The method of this study was pure in vivo laboratory experiment with a completely randomized design to 28 old male DDY strain mices divided into five groups; normal control, negative control, concentration $20.6 \mathrm{mg} / 20 \mathrm{gBW}, 41.2 \mathrm{mg} / 20 \mathrm{gBW}$, and $82.4 \mathrm{mg} / 20 \mathrm{gBW}$. Fasting blood glucose measurements were performed after adaptation, ongoing treatment (day 15), and after treatment using glucosemeter. Data analysis used KruskallWallis test and Friedman test. The results showed that there was a significant GDP median difference of each groups $(\mathrm{p}=0.05)$, a nonsignificant GDP $\mathrm{m}_{2}$ median difference $(\mathrm{p}=0.08)$, and GDP ${ }_{3}$ median difference were not significantly different $(p=0.66)$. There was a statistically significant difference between median GDP - between each water fraction of lemon concentration groups $(\mathrm{p}=\mathrm{0.04})$. Conclusion, the water fraction of lemon has the effect of lowering blood glucose.
\end{abstract}

Key words: Blood glucose, citrus limon, diabetes mellitus

Korespondensi: Rina Permatasari. Prodi Sarjana Kedokteran Fakultas Kedokteran, Universitas Islam Bandung, Jl. Tamansari No. 22, Kota Bandung, Provinsi Jawa Barat HP: 089655717461 E-mail: permatasarina@yahoo.co.id 


\section{Pendahuluan}

Peningkatan perubahan pola hidup masyarakat ternyata menimbulkan sejumlah masalah termasuk peningkatan prevalensi penyakit degeneratif, salah satunya adalah diabetes melitus. Diabetes melitus merupakan salah satu penyakit yang menjadi masalah terbesar pada abad 21. Menurut estimasi International Diabetes Federation (IDF) tahun 2015, sebanyak 415 juta orang dewasa berusia 20-79 tahun di seluruh dunia menderita DM. Tahun 2040 diprediksi 642 juta orang akan mengalami DM. ${ }^{1}$

Demikian pula mengkhawatirkan adalah tingginya prevalensi dua faktor yang terkait dengan peningkatan risiko diabetes, yaitu sindrom metabolik dan obesitas. ${ }^{2}$ Obesitas terjadi pada $60-80 \%$ penderita DM tipe 2 dan berkonstribusi utama terhadap resistensi insulin. Peningkatan asam lemak bebas serum dan deposit trigliserida intraseluler dan kolesterol ditemukan pada pasien obesitas, hal ini disebut metabolic overload (asupan kalori dan lipid yang tinggi). Hal ini dapat menurunkan respons jaringan terhadap insulin. Peningkatan asam lemak juga menyebabkan perubahan sekresi insulin dalam sel $\beta .3$

Obesitas (terutama obesitas viseral) dan resistensi insulin sering disertai dengan sekelompok kelainan yang disebut sindrom metabolik yang mencakup intoleransi glukosa, trigliserida tinggi, kolesterol HDL rendah, dan hipertensi. ${ }^{4}$

Penuaan adalah fenomena alami yang dialami setiap makhluk hidup. Karakteristik penuaan yang khas dan melibatkan semua sel, jaringan, dan organ dalam inflamasi ringan yang terjadi secara kronik mengarah pada degradasi secara progresif. Dalam kondisi ini, lemak tubuh akan cenderung meningkat apalagi bila diikuti dengan diet tinggi lemak akan berakibat pada peningkatan berat badan atau obesitas. ${ }^{5}$

Obat tradisional yang telah lama menjadi sumber perawatan dan populer dalam pemeliharaan kesehatan, pencegahan, dan juga pengobatan penyakit terutama penyakit kronik di negara di Asia Tenggara. Negara anggota World Health Organization (WHO) telah secara resmi mengakui bahwa pengobatan tradisional dan komplementer berkontribusi terhadap kesehatan dan kesejahteraan masyarakat. ${ }^{6}$

Penggunaan obat herbal secara umum dianggap relatif aman karena berasal dari sumber alami. Kelebihan lain dari tanaman obat herbal di antaranya memiliki lebih dari satu senyawa aktif yang memiliki beberapa efek biologis, lebih murah, mudah didapatkan, dan memiliki efek samping yang lebih sedikit dibanding dengan obat sintetik.?

Buah lemon (Citrus limon) mengandung banyak komponen kimia alami termasuk senyawa fenolik (dominan flavonoid) dan nutrisi lainnya (vitamin, mineral, serat makanan, essential oil, dan karotenoid). ${ }^{8}$ Sebagian flavonoid mencegah perkembangan hiperglikemia dengan mengikat pati, meningkatkan glikolisis hepatik dan konsentrasi glikogen, serta menurunkan glukoneogenesis hepatik. ${ }^{9}$ Senyawa flavonoid sangat penting dalam menyeimbangkan makanan terutama perannya mencegah penyakit seperti obesitas, diabetes melitus, menurunkan kadar lemak darah, penyakit kardiovaskular, dan beberapa tipe kanker. ${ }^{8}$
Para peneliti telah menggunakan diet tinggi lemak untuk menghasilkan model tikus obesitas. Studi lain telah mengungkapkan bahwa diet tinggi lemak memicu hiperglikemia serta resistensi insulin, dan banyak peneliti telah memeriksa efeknya terhadap fisiologi otot dan hati dan pada transduksi sinyal insulin. Berdasar atas hal ini, dapat diterima bahwa diet tinggi lemak dapat digunakan untuk menghasilkan model tikus yang valid untuk sindrom metabolik dengan resistensi insulin dan fungsi sel beta yang terganggu. ${ }^{10}$

Sementaraitu, penelitian lemon yang menggunakan air sebagai pelarutnya pada mencit tua yang diberikan pakan tinggi lemak masih jarang dilakukan. Tujun penelitian inimengetahui perubahan kasus glukosa darah pada mencit tua yang diberi pakan tinggi lemak setelah pemberian protein dari buah lemon (citrus limon).

\section{Metode}

Metode penelitian ini adalah eksperimental laboratorium murni in vivo dengan desain rancangan acak lengkap. Penelitian dilakukan di Laboratorium Hewan Gedung Farmasi ITB dan Laboratorium Hewan Fakultas Kedokteran Universitas Islam Bandung pada bulan April-Juni 2018. Variabel bebas adalah fraksi air buah lemon yang dibuat di Laboratorium Sentral Universitas Padjadjaran dan variabel terikat kadar glukosa darah. Bahan penelitian yang digunakan adalah buah lemon (Citrus limon), akuades, pakan standar (CP551), dan pakan tinggi lemak (PTL) yang merupakan pakan standar yang dicampurkan telur bebek dan lemak sapi cair. Alat penelitian adalah corong pisah, beaker glass, tabung erlemeyer, statif dan ring, rotary evaporator, kandang untuk tiap kelompok, timbangan, spuit, sonde, dan glukometer.

Konsentrasi fraksi air lemon yang digunakan adalah 20,6 mg/20 gBB, 41,2 mg/20 gBB, dan 82,4 $\mathrm{mg} / 20$ gBB yang mengacu pada penelitian sebelumnya. Konsentrasi $8.000 \mathrm{mg}$, $16.000 \mathrm{mg}$, dan $32.000 \mathrm{mg}$ dikonversikan ke dalam bentuk dosis mencit sehingga didapatkan konsentrasi 20,8 mg/20 gBB, 41,6 mg/20 gBB, dan 83,2 mg/20 gBB. ${ }^{5}$ Selanjutnya dikalikan dengan persentase fraksi air buah lemon sebanyak $99 \%$ dari total fraksi yang didapatkan sehingga konsentrasi yang digunakan adalah 20,6 mg/20 gBB, 41,2 mg/20 $\mathrm{gBB}$, dan $82,4 \mathrm{mg} / 20 \mathrm{gBB}$. Hewan uji yang digunakan dalam penelitian ini adalah mencit tua jantan galur DDY dengan bobot 40-60 gram dan berusia 45-49 minggu. Hewan uji tersebut diadaptasi terlebih dahulu dengan lingkungan penelitian selama 30 hari karena menunggu ketersediaan fraksi air lemon, kemudian dibagi menjadi lima kelompok secara acak. Kelompok I, yaitu kontrol normal diberikan pakan standar (CP551) dan akuades; kelompok II, yaitu kontrol negatif diberikan pakan tinggi lemak dan akuades; kelompok III (perlakuan I) diberikan pakan tinggi lemak dan fraksi air buah lemon dengan konsentrasi $20,6 \mathrm{mg} / 20 \mathrm{gBB}$; kelompok IV (perlakuan II) diberikan pakan tinggi lemak dan fraksi air buah lemon dengan konsentrasi 41,2 mg/20 gBB; dan kelompok $\mathrm{V}$ (perlakuan III) diberikan pakan tinggi lemak dan fraksi air buah lemon dengan konsentrasi 82,4 mg/20 gBB. Semua hewan uji dilakukan penimbangan bobot 
mencit setiap hari dan diberi perlakuan selama 26 hari. Mencit dipuasakan selama 16 jam untuk diperiksa kadar glukosa darah sebanyak tiga kali, yakni setelah adaptasi, saat diberikan perlakuan (hari ke-15), dan setelah perlakuan. Darah mencit diambil dari ekor lalu tetesan darah dialirkan pada test strip yang terpasang pada alat glukometer. Setelah itu, perdarahan ekor mencit dihentikan dan dalam waktu 15 detik pada layar tertera kadar glukosa dalam satuan mg/dL.

Data yang diperoleh dari penelitian berupa kadar glukosa darah diuji statistik dengan Uji Normalitas Saphiro-Wilk, kemudian Uji Kruskal-Wallis, dan selanjutnya Uji Friedman untuk mengetahui perbedaan bermakna antar setiap kelompok. Penelitian ini telah mendapat izin (ethical clearance) dari Komite Etik Penelitian Kesehatan Fakultas Kedokteran Universitas Islam Bandung melalui surat Nomor: 268/Komite Etik.FK/III/2018.

\section{Hasil}

Uji normalitas yang dipergunakan adalah metode Uji Shapiro-Wilk yang disajikan pada Tabel 1 . Uji normalitas dengan Shapiro-Wilk menunjukkan bahwa asumsi distribusi normal tidak terpenuhi dikarenakan nilai p GDP dalam kelompok perlakuan $82,4 \mathrm{mg}$ di bawah kemaknaan yang ditentukan (alpha 0,05).

Tabel 1 Uji Asumsi Distribusi Normal GDP

\begin{tabular}{cccc}
\hline \multirow{2}{*}{ Kelompok } & \multicolumn{3}{c}{ Shapiro-Wilk } \\
\cline { 2 - 4 } & $\left.\mathbf{p ~ ( G D P} \mathbf{1}_{\mathbf{1}}\right)$ & $\mathbf{p}\left(\mathbf{G D P}_{\mathbf{2}}\right)$ & $\mathbf{p}$ (GDP $\mathbf{3}_{\mathbf{3}}$ ) \\
\hline Normal & 0,41 & 0,6 & 0,44 \\
Negatif & 0,18 & 0,53 & 0,47 \\
$20,6 \mathrm{mg}$ & 0,3 & 0,06 & 0,89 \\
41,2 mg & 0,87 & 0,73 & 0,49 \\
$82,4 \mathrm{mg}$ & 0,81 & 0,88 & 0,04 \\
\hline
\end{tabular}

Distribusi frekuensi yang dianalisis adalah median karena asumsi distribusi normal yang tidak terpenuhi tersebut. Analisis uji beda yang dilakukan adalah uji nonparametrik, Uji Kruskal-Wallis untuk menganalisis beda GDP antarkelompok masing-masing dan Uji Friedman untuk menganalisis beda GDP ${ }_{1}$ sampai GDP $_{3}$ yang dijelaskan pada Tabel 2.
Pada tabel distribusi frekuensi dan analisis GDP didapatkan median GDP pertama sampai ketiga dalam setiap kelompok perlakuan. Nilai p GDP ${ }_{1}$ Uji KruskalWallis didapatkan nilai 0,05 yang menunjukkan perbedaan median GDP $_{1}$ signifikan antara setiap kelompok perlakuan.

Pada GDP diperoleh nilai $\mathrm{p}=0,08$ melebihi signifikansi yang ditentukan menunjukkan tidak terdapat perbedaan median $\mathrm{GDP}_{2}$ yang signifikan antara setiap kelompok perlakuan.

Pada GDP3 diperoleh nilai $\mathrm{p}=0,66$ lebih besar daripada kemaknaan yang ditentukan menunjukkan tidak terdapat perbedaan median GDP3 yang signifikan antara setiap kelompok perlakuan.

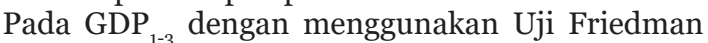
diperoleh nilai $\mathrm{p}=0,04$ yang signifikan menimbulkan perbedaan median GDP dari pemeriksaan pertama sampai ketiga antarkelompok perlakuan. Hal tersebut terlihat dalam gambar perubahan median, yakni secara keseluruhan terjadi perubahan median GDP dari pemeriksaan pertama sampai ketiga dalam setiap kelompok percobaan.



Gambar Perubahan Median GDP

Berdasar atas gambar perubahan median GDP di atas dapat diketahui bahwa pada pemeriksaan GDP yang kedua $\left(\mathrm{GDP}_{2}\right)$, median kadar glukosa darah puasa mengalami peningkatan pada semua kelompok. Median kadar glukosa darah puasa pemeriksaan ketiga $\left(\mathrm{GDP}_{3}\right)$ menurun pada setiap kelompok.

\section{Pembahasan}

Hasil pengukuran kadar GDP ${ }_{1}$ dalam masa adaptasi

Tabel 2 Distribusi Median dan Analisis GDP

\begin{tabular}{|c|c|c|c|c|c|c|c|}
\hline Kelompok & GDP $_{1}$ & p GDP ${ }_{1}^{*}$ & GDP $_{2}$ & p GDP ${ }_{2}^{*}$ & $\mathbf{G D P}_{3}$ & p GDP $_{3}{ }^{*}$ & p GDP ${ }_{1-3}{ }^{* *}$ \\
\hline Normal & 105 & & 117 & & 111 & & \\
\hline Negatif & 139 & 0,05 & 156 & 0,08 & 105 & 0,66 & 0,04 \\
\hline $20,6 \mathrm{mg}$ & 125 & & 154 & & 89 & & \\
\hline $41,2 \mathrm{mg}$ & 122,5 & & 139 & & 91 & & \\
\hline $82,4 \mathrm{mg}$ & 111 & & 140,5 & & 107,5 & & \\
\hline Total & 122 & & 139 & & 103 & & \\
\hline
\end{tabular}


masih dalam batas normal dengan GDP kelompok kontrol negatif paling besar, sedangkan GDP kelompok kontrol normal sebagai yang terkecil. Hal ini menunjukkan bahwa makanan, minuman, dan kondisi lain tidak memengaruhi glukosa darah mencit selama masa adaptasi.

Hasil pemeriksaan GDP mengalami peningkatan pada semua kelompok. Kelompok kontrol negatif sebagai kelompok dengan median GDP2 terbesar dan hanya sedikit berbeda dengan kelompok perlakuan $20,6 \mathrm{mg}$. Kelompok kontrol normal menjadi kelompok dengan median GDP terkecil. Peningkatan tertinggi terjadi pada kelompok $82,4 \mathrm{mg}$ yang tidak berbeda jauh dengan kelompok 20,6 mg, sedangkan peningkatan terendah terjadi pada kelompok kontrol normal. Peningkatan terlihat terutama yang diberikan pakan tinggi lemak lebih tinggi daripada pakan standar. Peningkatan GDP diperkirakan pakan tinggi lemak efektif menimbulkan efek hiperglikemik pada penelitian ini. Studi lain telah mengungkapkan bahwa diet tinggi lemak memicu hiperglikemia serta resistensi insulin dan banyak peneliti telah memeriksa efeknya terhadap fisiologi otot dan hati serta pada transduksi sinyal insulin. ${ }^{10}$ Diperkirakan saat pemeriksaan glukosa darah puasa yang kedua (hari ke-15), dosis fraksi air buah lemon belum dapat menurunkan kadar glukosa darah.

Hasil pemeriksaan $\mathrm{GDP}_{3}$, median GDP menunjukkan penurunan pada ${ }^{3}$ semua kelompok, dengan median kelompok normal menjadi yang paling besar, sedangkan median GDP yang paling kecil ada dalam kelompok perlakuan 20,6 mg. Penurunan median tertinggi terjadi pada kelompok 20,6 mg dan penurunan terendah terjadi pada kelompok kontrol normal. Penurunan GDP yang muncul setelah perlakuan 26 hari tersebut kemungkinan disebabkan oleh kandungan flavonoid yang dapat menurunkan glukosa darah. Flavonoid yang berkhasiat sebagai antioksidan eksogen dapat menimbulkan efek kuratif terhadap sel beta pankreas dan meningkatkan sensitivitas insulin dengan menurunkan stres oksidatif dan mengurangi reactive oxygen species (ROS). Mekanisme ini meredam radikal bebas secara langsung dengan menyumbangkan atom hidrogennya. Flavonoid akan teroksidasi oleh radikal menjadi senyawa yang lebih stabil dan kurang reaktif. ${ }^{11}$ Flavonoid juga menghambat GLUT-2 pada mukosa usus. Mekanisme penghambatan ini bersifat nonkompetitif sehingga dapat menurunkan absorbsi glukosa dan kadar glukosa darah dapat menurun. ${ }^{12}$

Selain itu, flavonoid dapat menghambat fosfodiesterase sehingga dapat menyebabkan sekresi insulin oleh sel beta pankreas. Flavonoid merupakan inhibitor alfa-glukosidase sehingga menghambat enzim alfa-glukosidase yang dibutuhkan untuk pemecahan karbohidrat sebelum diabsorbsi sebagai monosakarida. Mekanismekerja di atas mengakibatkan penurunan glukosa darah. ${ }^{13}$ Median GDP kelompok kontrol negatif ikut mengalami penurunan diduga karena seiring waktu penelitian yang bertambah, mencit sudah mengalami adaptasi berupa sel beta pankreas yang beradaptasi terhadap peningkatan kebutuhan akan insulin dengan cara meningkatkan sekresi insulin. ${ }^{14}$ Adaptasi sel beta tersebut dapat juga terjadi pada kelompok lain sehingga penurunan tersebut dapat tidak hanya disebabkan oleh kandungan flavonoid pada fraksi air lemon, akan tetapi penurunan tidak sebesar kelompok kontrol negatif.

Hasil analisis menggunakan Uji Friedman menunjukkan hasil yang signifikan bahwa terdapat perbedaan GDP dari pemeriksaan pertama sampai ketiga antarkelompok perlakuan. Hal ini menunjukkan bahwa fraksi air buah lemon mempunyai efek secara bermakna terhadap kadar GDP subjek penelitian. Namun, belum dapat ditentukan dosis manakah yang paling efektif untuk menurunkan kadar glukosa darah karena sebaran data yang tidak normal sehingga tidak dapat dilakukan uji lanjutan.

\section{Simpulan}

Simpulan penelitian adalah pakan tinggi lemak (PTL) memengaruhi kadar glukosa darah dibanding dengan yang hanya diberi pakan standar. Fraksi air buah lemon (Citrus limon) memiliki efek menurunkan kadar glukosa darah pada mencit tua yang diberi pakan tinggi lemak (PTL).

\section{Ucapan Terima Kasih}

Ucapan terima kasih penulis sampaikan kepada Kepala Laboratorium Hewan Gedung Farmasi ITB dan Kepala Laboratorium Fakultas Kedokteran Universitas Islam Bandung.

\section{Daftar Pustaka}

1. Cho NH, Whiting D, Forouhi N, Guariguata L, Hambleton I, Li R, dkk. IDF diabetes atlas. Edisi ke-7. Brussels: International Diabetes Federation; 2015 .

2. Pradhan A. Obesity, metabolic syndrome, and type 2 diabetes: inflammatory basis of glucose metabolic disorders. Nutr Rev. 2008;65(12):1526.

3. McCance KL, Huether SE. Pathophysiology: the biologic basis for disease in adults and children. Edisi ke-7. St.Louis: Mosby; 2014.

4. Marques C, Meireles M, Norberto S. Highfat diet-induced obesity rat model. Adipocyte. 2016;5(1):11-21.

5. Yulianti AB, Widayanti, Rahmawaty I. Efek proteksi campuran ekstrak bawang putih, jahe gajah, dan lemon terhadap kadar kolesterol total darah pada tikus tua yang terpapar diet tinggi lemak. Prosiding SNaPP2O17 Kesehatan. 2017;3(1):215-21.

6. WHO. Traditional medicine action plan for the South-East Asia region. Geneva: WHO; 2015 [diunduh 2 Januari 2018]. Tersedia dari: http:// www.searo.who.int/entity/traditional_medicine/ en/.

7. Pathak K, Das RJ. Herbal medicine: a rational approach in health care system. Int $\mathrm{J}$ Herbal Med. 2013;1(3):86-9.

8. González-Molina E, Domínguez-Perles $\mathrm{R}$, Moreno DA, García-Viguera C. Natural bioactive 
compounds of Citrus limon for food and health. J Pharm Biomed Anal. 2010;51(2):327-45.

9. Shen $\mathrm{W}, \mathrm{Xu} \mathrm{Y}, \mathrm{Lu} \mathrm{YH}$. Inhibitory effects of citrus flavonoids on starch digestion and antihyperglycemic effects in hepG2 cells. 2012 Sept 8;60(38):9609-19.

10. Buettner R, Scholmerich J, Bollheimer LC. High-fat diets: modelling the metabolic disorders of human obesity in rodents. Obesity. 2008;15(4):798-808.

11. Sarian MN, Ahmed QU, So'ad SZ, Alhassan AM, Murugesu S, Perumal V, dkk. Antioxidant and antidiabetic effects of flavonoids: a structureactivity relationship based study. Biomed Res Int. 2017 Nov 28:1-14.
12. Gato T, Horita M, Nagai H, Nagatomo A, Nishida $\mathrm{N}$, Matsuura Y, dkk. Tiliroside, a glycosidic flavonoid, inhibits carbohydrate digestion and glucose absorption in the gastrointestinal tract. Mol Nutr Food Res. 2012;56(3):768-76.

13. Najafian M, Habibi E, Parichehreh Y, Kazem P, Bagher L. Core structure of flavonoids precursor as an antihyperglycemic and antihyperlipidemic agent: an in vivo study in rats. Acta Biochimica Polonica. 2010;57(4):553-60.

14. Ellenbroek JH, Töns HA, de Graaf N, Loomans CJ, Engelse MA, Vrolijk H, dkk. Topologically heterogeneous beta cell adaptation in response to high-fat diet in mice. PLoS ONE. 2013;8(2):5629. 